\title{
Work From Home: The Role of Work Engagement on Productivity During Covid-19 Corona Pandemic a Study in Teachers and Lectures in Yogyakarta Province and City Nears Yogyakarta
}

\author{
Kusmaryati D Rahayu ${ }^{1)}$ \\ Faculty of Economics and Business \\ Janabadra University \\ Yogyakarta 55231, Indonesia \\ kusmaryati@janabadra.ac.id
}

\author{
Wika Harisa $\mathrm{P}^{2)}$ \\ 2) Faculty of Economics and Business \\ Janabadra University \\ Yogyakarta 55231, Indonesia \\ Agnes Ratih Ari ${ }^{3)}$ \\ 3) Faculty of Economics and Business \\ Janabadra University \\ Yogyakarta 55231, Indonesia.
}

\begin{abstract}
Covid-19 Corona pandemic has overwhelmed the world since January 2020 and has spread in Indonesia in March 2020. After that, all the lifestyle is changed. The majority of people/employees work from home. Many offices, factories, and industries were closed because people are frightened of the virus covid-19 corona. Millions of people in the world have died from this virus. This research would explore how the teacher and lecturer work from home. Have they worked productively? This study aims to determine the effect of the work environment and stress on productivity mediated by work engagement while teacher and lecturer work from home because of the Covid-19 Corona pandemic. The sampling technique was convenient, with 151 respondents working and living in Yogyakarta Province and city nears Yogyakarta. Data is collected by questionnaire, Likert scale 1-7. The Data was analyzed by Multiple Linear Regression with intervening. The results showed that work environment and stress positively and significantly influenced productivity, but work engagement was not an intervening variable. Coefficient of Determination, Adjusted $R^{2}$ is 0.48 .
\end{abstract}

Keywords: work from home, work environment, stress, productivity, work engagement

\section{INTRODUCTION}

At the beginning of 2020, the world was met by horrendous news of the emergence of coronavirus (covid19) that spread worldwide, including to Indonesia. This disaster brings lots of effects such as limitation, even discontinuation of all common human activities so the virus won't spread massively. Therefore, the phrase Work from Home, which held meaning "to work, study, and pray from home," become familiar. One of the possible activities from home is teaching and learning activities, which is the main duty of teachers and lecturers towards students and university students online. The change in teaching and learning activities triggers stress for teachers and lecturers because they had to arrange a work environment at home to be disturbed by other family members' activities (spouse, kids, etc.) during working hours. Strong commitment and motivation (work engagement) are needed if teachers and lecturers were to remain productive. Research about WFH during coronavirus pandemic (covid-19) hasn't been done before. The previous empirical study was about telecommuting, which means working outside of the usual workplace done on purpose and with careful planning because there was room for flexibility and efficiency at work for the employees. This research aims to know how productive teachers and lecturers while working from home during the urgency of coronavirus covid-19 that is measured by stress level and work environment whilst noticing the role of work engagement, a case study in Yogyakarta Province and cities near the area.

\section{REVIEW OF THE LITERATURE AND HYPOTHESIS}

WFH (Stress and work environment) and Productivity The measurement of teachers' and lecturers' performance or productivity level is based on Indonesian Law of Teachers and Lecturers no 14, 2005 (Undang-Undang Guru dan Dosen no 14 Tahun 2005). The previous research [1] proved employees who work at home have a higher level of productivity than employees who work at the office and have higher life satisfaction, which increased their productivity level. The results of Bloom's research supported this statement as well; employees that work from home are more productive and happier[2]. Kim and team[3] found the influence of the work environment towards the productivity of employees.[4] supports the statement that employees who are allowed to work at home have a lower absence level, lower disturbance at work, more flexible work schedules, a higher ability to control their personal matters, and more time for family and work. Work From Home give flexitime to do the work. And the flexitime significantly increase job satisfaction. [5].

H1: Work environment at home(WFH) positively influence the productivity of teachers and lecturers. 
However, on the other side, working at home can also increase the stress level because employees have to balance office work and domestic/housework. Research by I Gede Riana[6] found out that stress negatively influences work satisfaction but does not directly influence employees' performance/productivity. Research by Kazekami[1] stated that stress does not directly influence the productivity of employees. Work from Home complicates balancing work and home roles because it increases home to work conflict. [7].Teaching is stressfull. Teachers Are burned out at any given time. In comparison with other professions, teachers show high levels of exhaustion. Job stress caused by the combination of work overload and time pressure and low job control. [8].

H2: Stress by working at home (WFH) negatively influence the productivity of teachers and lecturers.

\section{Work engagement and Productivity}

Work engagement does not happen out of the blue; organizations has to provide employees work authority, intrinsic reward, etc. [9], [10] found out that employees who have high work engagement would be able to decrease their stress level so that through the support of their bosses/superiors, would be able to perform highly. [11],[12] stated that employees would have a high level of contribution if there were effective supervision, support from the organizations that would generate high performance. [13] during their research stated, employees' contribution directly influences performance, even though it is relatively small. Engagement was negatively associated with perceived stress and burnout.[14]. Work engagement influences positively of job performance.[15].Researcher stated that engaged worker perform better than non engaged workers, because they often experience positive emotions, include happines, joy and enthuasiasm.[16]

H3: Work engagement positively influences the productivity of teachers and lecturers.

\section{METHODS}

\section{Sample}

Subjects in this research are teachers and lecturers who work in Yogyakarta province questionnaire during June-July 2020 period. The questionnaire consists of 40 items questions and cities near the area, and also called as population. At the same time, the sample was collected by purposive sampling technique. The sample has a few conditions; teachers and lecturers who have been certified, who have passed professionalism qualifications as an educator. The amount of samples that are used is 151 people with a convenience method.

\section{Questionnaire}

Data were collected by. The question consists of variable $\mathrm{X}_{1}=$ work environment during wfh, 10 items, $X_{2}=$ stress during wfh, 10 items, from $Y=$ productivity during wfh, 10 items and $\mathrm{M}=$ employees enggagement during wfh, 10 items. The questionnaire is measured quantitatively with the LIKERT scale, which has ranged from 1 to $7.1=$ Strongly Disagree and 7= Strongly Agree.

\section{Statistical Analysis}

Instrument test consists of validity and reliability test. The validity test shows how accurate and precise a tool can function; a method used is product-moment Pearson. A reliability test is to measure the consistency of a tool (questionnaire). Measured by Cronbach's Alpha technique, it is considered reliable if the Cronbach alpha is bigger (>) than 0.70 (Ghozali, 2012).

If the data meets the condition, we proceed to the classical assumption test consisting of the normality test, heteroscedasticity test, and multicollinearity test (Ghozali, 2012). A multicollinearity test is done to find out whether, in a regression model, there is a correlation between free variables. A good regression is free from multicollinearity if the Variance Inflation Factor (VIF) $<10$ or if Tolerance $>$ 0.10 . The heteroscedasticity test is to verify/examine if, in the regression model, there is a variance dissimilarity from residual observation. A good regression happens when there is no heteroscedasticity. The tool used to examine is the Glesjer test (prob. Sign. > 0.05). The normality test is to find out that in the regression model, the residual is distributed normally. It is done with the Kolmogorov Smirnov test. The other test is Goodness of Fit, which consists of Coefficient Determination (Adjusted $R^{2}$ ), the goodness of fit $\mathrm{F}$, and Hypothesis test (t-test).

\section{RESULTS}

\section{Discussion}

Respondents characteristics. Respondents are 151 people. $70.2 \%$ are women, and $29.3 \%$ are men. $80,1 \%$ are teachers, and $19.9 \%$ are lecturers. Respondents are from outside Yogyakarta Province (70.9\%), and only 29.1\% from Yogyakarta province. $62.9 \%$ hold a Bachelor's degree, $31.8 \%$ hold a Master's degree, and 5\% hold Ph.D. and Associate degree. $80 \%$ has more than 10 years of experience in work. Therefore, $45 \%$ of respondents are more than 50 years old, $30 \%$ are between $41-50$ years old, and the rest $(25 \%)$ are under 40 years old. More than $86 \%$ of respondents are married, about $9 \%$ are single, and the rest of the respondents (5\%) are widower/widow.

The results of reliability test showed that each item of the questions is reliable (Cronbach Alpha $>0.70, \mathrm{X}_{1}=0.94 ; \mathrm{X}_{2}=$ $0.87 ; \mathrm{X}_{3}=0.91$ and $\left.\mathrm{Y}=0.86\right)$. The results of the validity test towards all the questions are valid. With total samples are 151 with $\mathrm{df}=\mathrm{n}-3$, then it is obtained $151-3=149$, so that this included in the level of trust $95 \%$ or $\alpha=5 \%$ so $r$ table $=0.165$. Since r Count (take a look at table 2) is bigger than $r$ table, then it can be concluded that all the questions are valid. The multicollinearity results towards the variables of this research showed that all free variables meet the condition: VIF of Work environment is $1.470<10$ or Tolerance level is $0.680>0.10$. VIF of Stress is $1.402<10$ or Tolerance level is $0.713>0.10$. VIF of Work engagement is $1.341<10$ or Tolerance level is $0.746>0.10$. The results of the Glesjer test is in table 4 . The value of significance probability of Stress, Work Environment, and Work engagement variables are listed in order: $0.282>$ $0.05 ; 0.206>0.05$ and $0.902>0.05$. 
From the results, it can be concluded that heteroscedasticity did not happen. The results of the normality test by Kolmogorov Smirnov. (Table 5) showed the value of $\mathrm{K}-\mathrm{S}=$ 0.063 , and the significance level is at $0.200>0.05$, which means that the residual data distributed normally. The results of the Goodness of Fit Model, the value of Adjusted $\mathrm{R}^{2}$ is 0.456. This means the Work environment and Stress's ability to explain the variation of variables on the teachers and lecturers' Productivity. In contrast, they work from home is $45.6 \%$, whereas the coefficient determination when mediation variable, Work engagement is included, the amount of Adjusted $R^{2}$ increased to 0.482. From the Goodness of fit $\mathrm{F}$ test, it is obtained that the value of $F$ Count is 47.535 with a probability level is at $0.00<0.05$, so the regression model can be used to predict Work environment, Stress, Work engagement, influence the productivity of teachers and lecturers.

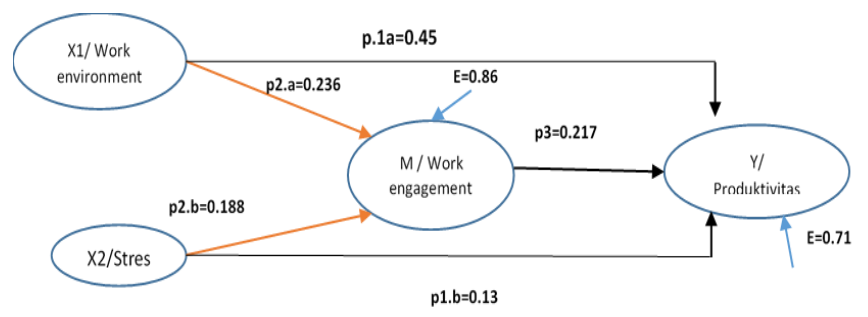

Fig. 1. Completely Standarized Multi linier Regression coefficient

The regression equation:

(1) Productivity $=14.028+0.405 \mathrm{~W}$. Envi +0.090 Stress $+0.217 \mathrm{~W}$. Engage

From the t-test that includes the work engagement variable as the independent variable, then the stress variable becomes insignificant or doesn't influence the productivity of employees (Y).

(2) Productivity $=21.092+0.456 \mathrm{~W}$. Envi+ 0.131 Stress.

Stress and work environment variables do have a significantly positive influence on the productivity of teachers and lecturers.

(3) Work Engagement $=32.603+0.236 \mathrm{~W}$. Envi +0.188 Stress.

Stress and work environment variables do have a significantly positive influence on the work engagement variable. The role of work engagement, in this case, is a dependent variable.

The results from descriptive statistics about the work environment showed that $50 \%$ of respondents stated that family supports working productively. Still, only $40 \%$ of respondents stated they are satisfied with working from home (because of the limited facility), even though they can do it together with domestic work. Whereas related to stress during WFH, more than $50 \%$ of respondents are stressed because their family is not fully supportive, $40 \%$ because they couldn't be discipline, so their work is delayed, $40 \%$ because the working environment is not conducive, $45 \%$ felt bored and fed up of WFH, it is only $10-30 \%$ of respondents who weren't stressed during WFH. About work engagement, $63 \%$ of respondents are passionate about doing their work, more than $70 \%$ are proud of their work and profession, $60 \%$ felt their work is so challenging, $50 \%$ always feel motivated while working. In respondents' response about their productivity during WFH, 60\% stated that they remain productive, more efficient, and often spent more than their working hours. Only $50 \%$ feel more creative and innovative. However, from the perspective of time and target accuracy, only 35\% stated they are on time, $37 \%$ work without technology impediment, only $25 \%$ work more than what's being assigned to them.

The results from The Regression Analysis the influence of work environment(X1), stress(X2) towards productivity (Y) by mediation/intervening (M) work engagement, it is obtained that work engagement is not mediation that influences work environment and stress towards productivity. It can be seen in equation number (2). The probability level of both significant independent variables, work environment (X1, sign. 0.00) and Stress (X2, sign. 0.025), accordingly work environment positively influence at the value of 0.456 and significant (sig. $0.00<0.05$ ) towards the productivity of teachers and lecturers.

The results of this research support a few previous studies, for example, the research by[4] about employees who are permitted to work at home have low absence level, low disturbance towards their job, more flexible about their work schedule. Whilst the research by Kazekami [1] that stated employees who work at home have a much higher level of productivity compared to those who work at the office, increase their life satisfaction, increase their productivity level is not completely supported by this research, because of the descriptive statistic results that showed only around half of the respondents stated they remain productive during wfh, more efficient, more creative and innovative. The respondents' productivity in this research is low, which is understandable since working at home, in this case, happened because of an urgent situation, unlike telecommuting, which was intentional and well-planned by the company of the previous studies, so that the facility needed is complete.

Therefore, this research answers the first hypothesis, states that the work environment during wfh positively influences teachers' and lecturers' productivity.

Stress has a positive influence at the value of 0.131 , significant (sig.0.025<0.05). The results of these calculations are supported by respondents' descriptive data that showed only $50 \%$ of respondents are stressed because their family is not fully supportive during wfh, works are delayed, feeling bored and fed up. This research supports Bloom's[2] that employees who work from home far happier than those who work at the office or the enterprise. This research does not align with the study by I Gede Riana et al. [6] that stress negatively and significantly influences work satisfaction, nevertheless does not directly influence employees' performance/productivity. This study proved that the second 
hypothesis states that stresses during wfh negatively influence teachers, and lecturers' productivity is not proven.

In the Multiple Regression equation (1), work engagement has a positive influence on productivity at the level of 0.217 and significant (sign. 0.004) and supported by respondents' descriptive, more than half of them remain passionate and motivated challenged during wfh. This research supports previous researchers[9] who found out that employees who have high level of engagement will decrease their stress, their bosses/superiors' support to perform highly. Other researchers [11] stated that the effort and contribution of the employees would deliver high productivity. The analysis of this research proved the third hypothesis states that the employees' contribution towards their job (work engagement) positively influences the productivity of teachers and lecturers.

\section{CONCLUSION}

This research gives an empirical overview of how work environment and stress influence teachers and lecturers' productivity while they work from home, mediated by work engagement. The results of this research showed that the work environment positively influences the productivity of teachers and lecturers. Nevertheless, stress turned out to positively influence the productivity of teachers and lecturers as well. This means the better the work environment at home, the higher the teachers' and lecturers' productivity level. The same way applies to stress. Although the coefficient of stress relatively small. Whilst work engagement variable is insignificant as mediation variable, however as the independent variable, it has significant influence; adjusted $R 2=$ 0.482 showed that the productivity of teachers and lecturers could be explained by the work environment, stress, and work engagement as much as $48.2 \%$, and the rest by other variables outside of this research.

\section{Acknowledgments}

I would like to express my gratitude to Janabadra University/ Faculty of Economics and Business for research funding and facilities.

\section{REFERENCES}

S. Kazekami, "Mechanisms to improve labor productivity by performing telework," Telecomm. Policy, vol. 44, no. 2, p. 101868 2020, doi: 10.1016/j.telpol.2019.101868

[2] N. Bloom, "To raise productivity, let more employees work from home," Harv. Bus. Rev., no. JAN-FEB, 2014.

[3] J. Kim, C. Candido, L. Thomas, and R. de Dear, "Desk ownership in the workplace: The effect of non-territorial working on employee workplace satisfaction, perceived productivity and health," Build. Environ., vol. 103, pp. 203-214, 2016, doi:

10.1016/j.buildenv.2016.04.015.

[4] A. Azadeh and M. Zarrin, "An intelligent framework for productivity assessment and analysis of human resource from resilience engineering, motivational factors, HSE and ergonomics perspectives," Saf. Sci., vol. 89, pp. 55-71, 2016, doi: 10.1016/j.ssci.2016.06.001.

[5] C. Kröll and S. Nüesch, "The effects of flexible work practices on employee attitudes: evidence from a large-scale panel study in Germany," Int. J. Hum. Resour. Manag., vol. 30, no. 9, pp. 15051525, 2019, doi: 10.1080/09585192.2017.1289548.

[6] R. G. I, "Managing Work Family Conflict and Work Stress through Job Satisfaction and Its Impact on Employee Performance," J. Tek. Ind., vol. 20, no. 2, p. 127, 2019, doi: 10.9744/jti.20.2.127-134.

[7] J. Delanoeije, M. Verbruggen, and L. Germeys, "Boundary role transitions: A day-to-day approach to explain the effects of homebased telework on work-to-home conflict and home-to-work conflict," Hum. Relations, vol. 72, no. 12, pp. 1843-1868, 2019, doi: 10.1177/0018726718823071.

[8] J. J. Hakanen, A. B. Bakker, and W. B. Schaufeli, "Burnout and work engagement among teachers," J. Sch. Psychol., vol. 43, no. 6 , pp. 495-513, 2006, doi: 10.1016/j.jsp.2005.11.001.

[9] S. W. Kang and S. D. Kang, "High-commitment human resource management and job stress: Supervisor support as a moderator,' Soc. Behav. Pers., vol. 44, no. 10, pp. 1719-1731, 2016, doi: 10.2224/sbp.2016.44.10.1719.

[10] M. Attridge, "Measuring and managing employee work engagement: A review of the research and business literature," $J$ Workplace Behav. Health, vol. 24, no. 4, pp. 383-398, 2009, doi: 10.1080/15555240903188398.

[11] S. Osborne and M. S. Hammoud, "Effective Employee Engagement in the Workplace," Int. J. Appl. Manag. Technol., vol. 16, no. 1, pp. 50-67, 2017, doi: 10.5590/IJAMT.2017.16.1.04

[12] N. P. Monteiro, M. Valente, and O. R. Straume, "Does remote work improve or impair firm labour productivity? Longitudinal evidence from Portugal," CESifo Work. Pap., vol. 7991, no. December, 2019.

[13] A. Shantz, K. Alfes, C. Truss, and E. Soane, "The role of employee engagement in the relationship between job design and task performance, citizenship and deviant behaviours," Int. J. Hum. Resour. Manag., vol. 24, no. 13, pp. 2608-2627, 2013, doi: 10.1080/09585192.2012.744334.

[14] T. C. T. Fong and Siu-Man Ng, "Measuring engagement at work: Validation of the Chinese version of the utrecht work engagement scale," Int. J. Behav. Med., vol. 19, no. 3, pp. 391-397, 2012, doi: 10.1007/s12529-011-9173-6.

[15] O. M. Karatepe, E. Beirami, M. Bouzari, and H. P. Safavi, "Does work engagement mediate the effects of challenge stressors on job outcomes? Evidence from the hotel industry," Int. J. Hosp. Manag., vol. 36, pp. 14-22, 2014, doi: 10.1016/j.ijhm.2013.08.003.

[16] S. Vincent-Höper, C. Muser, and M. Janneck, "Transformational leadership, work engagement, and occupational success," Career Dev. Int., vol. 17, no. 7, pp. 663-682, 2012, doi: $10.1108 / 13620431211283805$. 